\title{
PENGARUH TERAPI MUSIK TERHADAP PENURUNAN INTENSITAS NYERI PADA IBU INPARTU KALA I FASE AKTIF
}

\author{
THE EFFECT OF MUSIC THERAPY ON DECREASING THE \\ INTENSITY OF PAIN IN MOTHER INPARTU I PHASE ACTIVE \\ Sofia Mawaddah ${ }^{1}$
}

${ }^{1}$ Jurusan Kebidanan, Poltekkes Kemenkes Palangka Raya, Kalimantan Tengah, Indonesia (penulis korespondensi: sofizline@gmail.com)

\begin{abstract}
ABSTRAK
Latar belakang: Sebagian besar ibu bersalin dengan metode persalinan normal mengalami nyeri pada waktu menjelang persalinan khususnya pada kala I (kala pembukaan), rasa sakit terjadi karena adanya aktifitas besar di dalam tubuh ibu untuk mengeluarkan bayi. Nyeri ini semakin lama semakin kuat, penanganan dan pengawasan nyeri persalinan terutama pada kala I fase aktif sangat penting, karena ini sebagai titik penentu apakah seorang ibu bersalin dapat menjalani persalinan normal atau dibantu dengan suatu tindakan karena adanya penyulit.
\end{abstract}

Metode: Penelitian ini menggunakan Quasy Eksperiment dengan desain Two Eksperiment Pre-Post Test. Ada 2 kelompok pada penelitian ini yaitu $17 \mathrm{ibu}$ inpartu kala I fase aktif yang diberikan terapi musik suling Baluwung dan 17 ibu inpartu kala I fase aktif yang diberikan terapi aroma terapi Esensial oil mawar. Analisis bivariat menggunakan uji Mann Whitney.

Hasil: Penelitian menunjukkan intensitas nyeri sesudah terapi essential oil mawar pada ibu Inpartu Kala I Fase aktif dengan probabilitas yang dihasilkan sebesar 0.623, sehingga lebih tinggi dibandingkan intensitas nyeri sesudah terapi musik pada ibu Inpartu Kala I Fase aktif.

Kesimpulan: Pemberian terapi musik lebih efektif menurunkan intensitas nyeri pada ibu Inpartu Kala I Fase aktif dibandingkan pemberian terapi essential oil mawar.

\section{Kata Kunci:Terapi Musik, Nyeri Persalinan, Kala I Fase Aktif}

\section{ABSTRACT}

Background: Most women giving birth with normal delivery methods experience pain in the time leading up to labor, especially in the first stage (when opening), the pain occurs because of the great activity in the mother's body to expel the baby. This pain is getting stronger and stronger, the handling and supervision of labor pain, especially in the first phase of the active phase is very important, because this is a determining point whether a maternity mother can undergo a normal delivery or be assisted with an action due to complications.

Method: This study uses a Quasy Experiment with the design of the Two Experiment PrePost Test. There were 2 groups in this study, 17 in the first phase active mothers who were given Baluwung distilled music therapy and 17 in the first phase active mothers who were given aromatherapy therapy in rose essential oil. Bivariate analysis using the Mann Whitney test.

Results: The study showed the intensity of pain after rose essential oil therapy in First Stage Inpartu mothers The active phase with the resulting probability was 0.623 , so it was higher than the intensity of pain after music therapy for First Stage Inpartu mothers active phase.

Conclusion: The provision of music therapy is more effective in reducing the intensity of pain in mothers Inpartu Kala I Active phase than the administration of rose essential oil therapy.

Keywords: Music Therapy, Labor Pain, Active Phase I Stage 


\section{PENDAHULUAN}

Berdasarkan hasil riset Kesehatan Dasar Indonesia tahun 2017 didapatkan bahwa proporsi kelahiran berdasarkan metode persalinan normal di Indonesia sebanyak 89,2\% sedangkan di Provinsi Kalimantan Tengah sebanyak $89,8 \%{ }^{1}$

Pada proses persalinan normal tentunya seorang ibu akan merasakan rasa nyeri yang menjalar sampai tulang belakang ibu.nyeri persalinan pada tahap pertama atau kala 1 disebabkan karena kontraksi rahim yang menyebabkan dilatasi dan penipisan servik serta ischemia rahim akibat kontraksi miometrium. Nyeri ini semakin lama semakin kuat. Karena nyeri yang semakin kuat inilah seringkali ibu bersalin meminta untuk diberikan obat-obatan analgesic atau dilakukan operasi caesar.

Laporan SDKI Tahun 2017 menunjukkan bahwa 17\% kelahiran hidup dalam 5 tahun sebelum survey dari wanita 1549 tahun yang dilahirkan melalui proses bedah Caesar. Persentase persalinan bedah Caesar meningkat dari 7\% pada SDKI 2007 menjadi 17\% pada SDKI tahun $2017 .^{2}$

Nyeri persalinan yang berat akan menimbulkan stress menyebabkan melemahnya kontraksi rahim dan berakibat pada persalinan lama atau kala I lama.

Jika hal ini tidak teratasi akan merugikan ibu dan menimbulkan resiko distress janin yang berakibat pada kematian ibu dan bayi, sehingga penanganan dan pengawasan nyeri persalinan terutama pada kala I fase aktif menjadi sangat penting, karena ini sebagai titik penentu apakah seorang ibu bersalin dapat menjalani persalinan normal atau diakhiri dengan suatu tindakan karena adanya penyulit yang diakibatkan karena nyeri yang sangat hebat. ${ }^{3}$

Saat ini, terdapat berbagai macam cara mengatasi rasa nyeri untuk proses persalinan baik secara farmakologis atau menggunakan obat maupun non- farmakologis atau tanpa obat-obatan. Cara-cara farmakologis adalah penggunaan obat-obatan seperti penggunaan analgesia yaitu berupa cairan yang dimasukan ke dalam tubuh sehingga tidak merasakan nyeri atau kontraksi.

Pada kenyataannya, penggunaan analgesia memiliki dampak negatif seperti depresi, gangguan pernapasan ibu maupun janin, mual, muntah hingga ketergantungan. ${ }^{4}$ Adapun cara non-farmakologis yaitu dengan cara mengurangi hingga menghilangkan nyeri tanpa penggunaan obat-obatan sehingga efek negatif dapat dihindari. Cara nonfarmakologis yang sering digunakan saat ini seperti terapi manual terapi musik, relaksasi, dan hypnobirthing.

Untuk terapi relaksasi dan hypnobrithing tidak semua orang atau tenaga kesehatan boleh melakukannya, harus dilakukan oleh Praktisi yang sudah bersertifikat. Metode penurunan nyeri secara non farmakologis yang lain adalah dengan terapi musik.

Terapi musik menawarkan suatu metode distraksi yang dapat menurunkan nyeri dan meningkatkan keadaan rileksasi yang mendalam yang dapat mengalihkan perhatian ibu dari rasa sakit saat bersalin. Terapi ini bisa dilakukan oleh semua tenaga kesehatan tidak harus dengan seorang Praktisi khusus.

Musik bekerja pada sistem saraf otonom yaitu bagian sistem saraf yang bertanggung jawab mengontrol tekanan darah, denyut jantung dan fungsi otak yang mengontrol perasaan dan emosi. Kedua sistem tersebut bereaksi sensitif terhadap musik. Ketika merasa sakit, kita menjadi takut, frustasi dan marah yang membuat kita menegangkan otot-otot tubuh, hasilnya easa sakit menjadi parah.

Mendengarkan musik secara teratur membantu tubuh relaks secara fisik dan mental, sehingga membantu menyembuhkan dan mencegah rasa sakit. Dalam proses persalinan, terapi musik berfungsi mengatasi kecemasan dan mengurangi rasa sakit karena mampu memberikan stimulus sensori yang menyenangkan sehingga menyebabkan pelepasan endorphin. ${ }^{5}$ Selain dengan terapi music, cara lain untuk menekan rasa nyeri selama proses persalinan menggunakan metode non farmakologis salah satunya ialah dengan aroma terapi menggunakan essential oil. ${ }^{6}$

Minyak atsiri berguna untuk meningkatkan kesehatan fisik dan juga memengaruhi kesehatan emosi. Saat ini penanganan yang sering digunakan untuk mengurangi rasa nyeri yaitu terapi komplementer aroma terapi dengan essential oil mawar, karena mawar mempunyai sifat-sifat antikonvulsan, antidepresi, anxiolytic dan bersifat sangat menenangkan. Minyak atsiri rose atau mawar disebut sebagai queen of oils. 
Mawar beraroma lezat, mempertahankan keseimbangan tubuh, merangsang perasaan nyaman dan mengurangi nyeri peada ibu bersalin). Sedangkan mawar menghadirkan kesan damai, mengurangi kejang dan mengatasi depresi. $^{7}$

\section{METODE}

Penelitian ini menggunakan Quasy Eksperiment, metode penelitian eksperiment diartikan sebagai metode penelitian yang digunakan untuk mencari pengaruh perlakuan tertentu terhadap yang lain dalam kondisi terkendali. ${ }^{8}$

Desain penelitian dalam penelitian ini adalah two eksperiment pre-test dan post-test with control grup dilakukan dua kali yaitu sebelum eksperimen (O1) disebut pre-test, dan sesudah eksperimen $(\mathrm{O} 2)$ disebut dengan posttest. Penelitian ini dilakukan di PMB Hj. Siti Saudah pada bulan Maret - Oktober 2019.

Populasi dalam penelitian ini adalah ibu inpartu yang partus di PMB Hj. Siti Saudah
Berdasarkan latar belakang yang telah diuraikan diatas, penulis merasa tertarik untuk meneliti bahwa metode pengurangan nyeri tidak hanya menggunakan obat (metode farmakologis) tetapi juga ada metode nonfarmakologis seperti menggunakan dan terapi musik.

pada bulan Maret - Juni 2019 dengan jumlah sampel 34 ibu yang dibagi menjadi 2 kelompok yaitu 17 ibu inpartu yang diberikan essensial oil dan 17 ibu inpartu diberikan terapi musik.

Teknik pengambilan sampel dalam penelitian ini menggunakan non probability sampling dengan teknik purposive sampling yaitu salah satu teknik sampling non random sampling. Instrument yang digunakan dalam penelitian ini adalah lembar penilaian nyeri FLACC,format isian, essential oil mawar,diffuser dan earphone. Uji statistik yang digunakan dalam penelitian ini adalah uji Mann Whitney.

masing variabel independen dan dependen.

Hasil analisis univariat digunakan untuk menghasilkan distribusi frekuensi dari masing-

Tabel 1. Distribusi Frekuensi Responden Terapi Essensial Oil Mawar dan Terapi Musik

\begin{tabular}{|c|c|c|c|c|}
\hline \multirow[t]{2}{*}{ Variabel } & \multicolumn{2}{|c|}{$\begin{array}{c}\text { Responden } \\
\text { Terapi } \\
\text { Essential Oil } \\
\text { Mawar }\end{array}$} & \multicolumn{2}{|c|}{$\begin{array}{c}\text { Responden Terapi } \\
\text { Musik }\end{array}$} \\
\hline & Frekuensi & $\%$ & Frekuensi & $\%$ \\
\hline \multicolumn{5}{|l|}{ Pendidikan } \\
\hline Tinggi & 15 & 88,24 & 17 & 100 \\
\hline Rendah & 2 & 11,76 & 0 & 0 \\
\hline \multicolumn{5}{|l|}{ Spassing } \\
\hline$>2$ tahun & 10 & 58,82 & 12 & 70,59 \\
\hline$<2$ tahun & 7 & 41,18 & 5 & 29,41 \\
\hline \multicolumn{5}{|l|}{ Paritas } \\
\hline Primipara & 5 & 29,41 & 4 & 23,53 \\
\hline Multipara & 10 & 58,82 & 13 & 76,47 \\
\hline Grandemultipara & 2 & 11,76 & 0 & 0 \\
\hline \multicolumn{5}{|l|}{ Dukungan } \\
\hline \multicolumn{5}{|l|}{ Keluarga } \\
\hline Didukung & 17 & 100 & 17 & 100 \\
\hline Tidak didukung & 0 & 0 & 0 & 0 \\
\hline
\end{tabular}


Berdasarkan Tabel 1, diketahui bahwa dari $17 \mathrm{ibu}$ inpartu yang diberikan terapi essential oil mawar, sebanyak 15 ibu $(88,24 \%)$ berpendidikan tinggi dan 2 ibu $(11,76 \%)$ berpendidikan rendah. pada kelompok ibu inpartu yang diberikan terapi musik, 17 ibu $(100 \%)$ berpendidikan tinggi. Hal ini menunjukkan, sebagian besar ibu inpartu yang diberikan terapi essential oil mawar dan terapi musik rata- rata berpendidikan tinggi.

Jarak kehamilan atau spassing pada kelompok ibu inpartu yang diberikan terapi essential oil mawar, sebanyak $10 \mathrm{ibu}(58,82 \%)$ yang jarak kehamilan atau spassing $>2$ tahun dan 7 ibu $(41,18 \%)$ yang jarak kehamilan atau spassing <2 tahun, sementara pada kelompok ibu inpartu yang diberikan terapi musik, sebanyak 12 ibu (70,59\%) yang jarak kehamilan atau spassing $>2$ tahun dan 2 ibu
$(29,41 \%)$ yang jarak kehamilan atau spassing $<2$ tahun. Hal ini menunjukkan, sebagian besar ibu inpartu yang diberikan terapi essential oil mawar dan terapi musik rata-rata jarak kehamilannya lebih dari 2 tahun.Paritas pada kelompok ibu inpartu yang diberikan terapi essential oil mawar, 5 ibu $(29,41 \%)$ primipara, $10 \mathrm{ibu}(58,82 \%)$ multipara dan 2 ibu $(11,75 \%)$ grandemultipara. sementara pada kelompok ibu inpartu yang diberikan terapi musik, 4 ibu $(23,53 \%)$ primipara dan 13 ibu $(76,47 \%)$. Hal ini menunjukkan, sebagian besar ibu inpartu yang diberikan terapi essential oil mawar dan terapi musik rata- rata ibu dengan paritas multipara. Dukungan keluarga pada ibu inpartu yang diberikan terapi essential oil mawar dan terapi musik, seluruh ibu inpartu mendapatkan dukungan keluarga saat proses persalinan.

Tabel 2. Skala Nyeri Sebelum dan Sesudah Terapi Essensial Oil Mawar dan Terapi Musik

\begin{tabular}{lcccccccc}
\hline Skala Nyeri & \multicolumn{3}{c}{$\begin{array}{c}\text { Responden Terapi } \\
\text { Essensial Oil Mawar }\end{array}$} & \multicolumn{2}{c}{$\begin{array}{c}\text { Responden Terapi } \\
\text { Musik }\end{array}$} \\
\cline { 2 - 9 } & Sebelum & Sesudah & Sebelum & \multicolumn{2}{c}{ Sesudah } \\
\cline { 2 - 9 } & $\mathbf{F}$ & $\mathbf{\%}$ & $\mathbf{F}$ & $\mathbf{\%}$ & $\mathbf{F}$ & $\mathbf{\%}$ & $\mathbf{F}$ & $\mathbf{\%}$ \\
\hline Nyeri ringan & 5 & 29,41 & 8 & 47,06 & 2 & 11,76 & 10 & 58,82 \\
Nyeri sedang & 8 & 47,06 & 9 & 52,94 & 8 & 47,06 & 6 & 35,29 \\
Nyeri berat & 4 & 23,53 & 0 & 0 & 7 & 41,18 & 1 & 5,88 \\
\hline \multicolumn{1}{c}{ Total } & $\mathbf{1 7}$ & $\mathbf{1 0 0}$ & $\mathbf{1 7}$ & $\mathbf{1 0 0}$ & $\mathbf{1 7}$ & $\mathbf{1 0 0}$ & $\mathbf{1 7}$ & $\mathbf{1 0 0}$ \\
\hline
\end{tabular}

Berdasarkan tabel 2 diketahui, sebelum diberikan terapi essential oil mawar, 5 ibu $(29,41 \%)$ merasakan nyeri ringan, 8 ibu $(47,06 \%)$ merasakan nyeri sedang dan $4 \mathrm{ibu}$ $(23,53 \%)$ merasakan nyeri berat, setelah diberikan terapi essential oil mawar, 8 ibu $(47,06 \%)$ merasakan nyeri ringan dan $9 \mathrm{ibu}$ $(52,94 \%)$ merasakan nyeri sedang. Hal ini menunjukkan bahwa rata-rata ibu inpartu merasakan nyeri sedang, sebelum dan sesudah terapi diberikan essential oil mawar.
Berdasarkan tabel 2 diketahui juga, sebelum diberikan terapi musik, 2 ibu $(11,76 \%)$ merasakan nyeri ringan, 8 ibu $(47,06 \%)$ merasakan nyeri sedang dan 7 ibu $(41,18 \%)$ merasakan nyeri berat, setelah diberikan terapi musik, $10 \mathrm{ibu}(58,82 \%)$ merasakan nyeri ringan dan 6 ibu $(35,29 \%)$ merasakan nyeri sedang dan $1 \mathrm{ibu}(5,88 \%)$ merasakan nyeri berat. Hal ini menunjukkan, rata-rata ibu inpartu sebelum diberikan terapi musik merasakan nyeri sedang dan sesudah diberikan terapi musik ibu inpartu merasakan nyeri ringan. 
Tabel 3. Tabulasi Silang Variabel dengan Intesitas Nyeri

Sebelum dan Sesudah Terapi Essential Oil Mawar Dan Terapi Musik

\begin{tabular}{|c|c|c|c|c|c|c|c|c|c|c|c|c|}
\hline \multirow[t]{4}{*}{ Variabel } & \multicolumn{6}{|c|}{ Terapi Essential Oil Mawar } & \multicolumn{6}{|c|}{ Terapi Musik } \\
\hline & \multirow{2}{*}{\multicolumn{3}{|c|}{$\begin{array}{l}\text { Sebelum } \\
\text { Skala Nyeri }\end{array}$}} & \multirow{2}{*}{\multicolumn{3}{|c|}{$\begin{array}{c}\text { Sesudah } \\
\text { Skala Nyyeri }\end{array}$}} & \multirow{2}{*}{\multicolumn{3}{|c|}{$\begin{array}{c}\text { Sebelum } \\
\text { Skala Nyeri }\end{array}$}} & \multirow{2}{*}{\multicolumn{3}{|c|}{$\begin{array}{c}\text { Sesudah } \\
\text { Skala nyeri }\end{array}$}} \\
\hline & & & & & & & & & & & & \\
\hline & Ringan & Sedang & Berat & Ringan & Sedang & Berat & Ringan & Sedang & Berat & Ringan & Sedang & Berat \\
\hline \multicolumn{13}{|l|}{ Pendidikan } \\
\hline Rendah & 0 & 1 & 1 & 1 & 1 & 0 & 0 & 0 & 0 & & & \\
\hline Tinggi & 5 & 7 & 3 & 7 & 8 & 0 & 2 & 8 & 7 & 8 & 7 & 2 \\
\hline \multicolumn{13}{|l|}{ Spassing } \\
\hline$>2$ tahun & 4 & 5 & 1 & 5 & 5 & 0 & 2 & 4 & 6 & 7 & 4 & 1 \\
\hline$<2$ tahun & 1 & 3 & 3 & 3 & 4 & 0 & 0 & 2 & 3 & 3 & 2 & 0 \\
\hline \multicolumn{13}{|l|}{ Paritas } \\
\hline Primipara & 1 & 3 & 1 & 2 & 3 & 0 & 0 & 1 & 3 & 2 & 2 & 0 \\
\hline Multipara & 4 & 4 & 2 & 4 & 6 & 0 & 2 & 3 & 4 & 8 & 4 & 1 \\
\hline Grande & & & & & & & & & & & & \\
\hline Multipara & 0 & 1 & 1 & 1 & 1 & 0 & 0 & 0 & 0 & 0 & 0 & 0 \\
\hline \multicolumn{13}{|l|}{ Dukungan } \\
\hline Keluarga & & & & & & & & & & & & \\
\hline Didukung & 5 & 8 & 4 & 8 & 9 & 0 & 2 & 8 & 7 & 8 & 9 & 0 \\
\hline $\begin{array}{l}\text { Tidak } \\
\text { didukung }\end{array}$ & 0 & 0 & 0 & 0 & 0 & 0 & 0 & 0 & 0 & 0 & 0 & 0 \\
\hline
\end{tabular}

Berdasarkan Tabel 3. menunjukkan 2 responden yang berpendidikan rendah, responden tidak merasakan nyeri ringan sebelum terapi essential oil mawar, sebanyak 1 responden $(50 \%)$ merasakan nyeri sedang sebelum terapi essential oil mawar, dan sebanyak 1 responden (50\%) merasakan nyeri berat sebelum terapi essential oil mawar. Tetapi, responden tidak merasakan lagi nyeri berat sesudah terapi essensial oil mawar, sebanyak 1 responden $(50 \%)$ merasakan nyeri ringan, dan sebanyak 1 responden $(50 \%)$ merasakan nyeri sedang.

Berdasarkan Tabel 3. menunjukkan 15 responden yang berpendidikan tinggi, 5 responden $(33,3 \%)$ merasakan nyeri ringan sebelum terapi essential oil mawar, sebanyak 7 responden $(46,7 \%)$ merasakan nyeri sedang, dan sebanyak 3 responden $(20 \%)$ merasakan nyeri berat sebelum terapi essential oil mawar. Tetapi, responden tidak merasakan lagi nyeri berat sesudah terapi essensial oil mawar, sebanyak 7 responden $(46,7 \%)$ merasakan nyeri ringan, sebanyak 8 responden $(53,3 \%)$ merasakan nyeri sedang.

Berdasarkan Tabel 3 juga menunjukkan 17 responden yang berpendidikan tinggi, 2 responden $(11,8 \%)$ merasakan nyeri ringan sebelum terapi musik, 8 responden (47\%) merasakan nyeri sedang sebelum terapi musik, dan sebanyak 7 responden $(41,2 \%)$ merasakan nyeri berat.

Berdasarkan tabel 3 menunjukkan 10 responden yang memiliki jarak kehamilan lebih dari 2 tahun, 4 responden (40\%) merasakan nyeri ringan sebelum terapi essential oil mawar, sebanyak 5 responden $(50 \%)$ merasakan nyeri sedang, dan sebanyak 1 responden (10\%) merasakan nyeri berat sebelum terapi essential oil mawar. Tetapi, responden tidak merasakan lagi nyeri berat sesudah terapi essensial oil mawar, sebanyak 5 responden $(50 \%)$ merasakan nyeri ringan, sebanyak 5 responden $(50 \%)$ merasakan nyeri sedang.

Berdasarkan Tabel 3.menunjukkan 7 responden yang memiliki jarak kehamilan kurang dari 2 tahun, 1 responden (14,2\%) merasakan nyeri ringan sebelum terapi essential oil mawar, sebanyak 3 responden (42,9\%) merasakan nyeri sedang, dan sebanyak 3 responden $(42,9 \%)$ merasakan nyeri berat sebelum terapi essential oil mawar. Tetapi, responden tidak merasakan lagi nyeri berat sesudah terapi essensial oil mawar, sebanyak 3 responden $(42,9 \%)$ merasakan nyeri ringan, sebanyak 4 responden $(57,1 \%)$ merasakan nyeri sedang. 
Berdasarkan Tabel 3 juga menunjukkan 12 responden yang memiliki jarak kehamilan lebih dari 2 tahun, 2 responden (16,7\%) merasakan nyeri ringan sebelum terapi musik, sebanyak 4 responden $(33,3 \%)$ merasakan nyeri sedang, dan sebanyak 6 responden $(50 \%)$ merasakan nyeri berat sebelum terapi musik. Tetapi, sesudah terapi musik sebanyak 7 responden $(58,3 \%)$ merasakan nyeri ringan, sebanyak 4 responden $(33,3 \%)$ merasakan nyeri sedang, dan hanya 1 responden $(8,4 \%)$ yang nyeri berat.

Berdasarkan Tabel 3 menunjukkan 5 responden yang memiliki jarak kehamilan kurang dari 2 tahun, responden tidak merasakan nyeri ringan sebelum terapi musik, sebanyak 2 responden $(40 \%)$ merasakan nyeri sedang, dan sebanyak 3 responden $(60 \%)$ merasakan nyeri berat sebelum terapi musik. Tetapi, responden tidak merasakan lagi nyeri berat sesudah terapi musik, sebanyak 3 responden $(60 \%)$ merasakan nyeri ringan, sebanyak 2 responden (40\%) merasakan nyeri sedang.

Berdasarkan Tabel 3 menunjukkan 5 responden yang memiliki paritas primipara, 1 responden (20\%) merasakan nyeri ringan terapi essensial oil mawar, sebanyak 1 responden (50\%) merasakan nyeri sedang, dan sebanyak 1 responden $(50 \%)$ merasakan nyeri berat sebelum terapi essensial oil mawar. Tetapi, responden tidak merasakan lagi nyeri berat sesudah terapi essensial oil mawar, sebanyak 1 responden (50\%) merasakan nyeri ringan, sebanyak 1 responden $(50 \%)$ merasakan nyeri sedang.

Berdasarkan Tabel 3 juga menunjukkan 4 responden yang memiliki paritas primipara, responden tidak merasakan nyeri ringan sebelum terapi musik, sebanyak 1 responden (25\%) merasakan nyeri sedang, dan sebanyak 3 responden $(75 \%)$ merasakan nyeri berat sebelum terapi musik. Tetapi, responden tidak merasakan lagi nyeri berat sesudah terapi musik, sebanyak 2 responden $(50 \%)$ merasakan nyeri ringan, sebanyak 2 responden $(50 \%)$ merasakan nyeri sedang.

Berdasarkan Tabel 3 menunjukkan 13 responden yang memiliki paritas multipara, 2 responden $(15,3 \%)$ merasakan nyeri ringan sebelum terapi musik, sebanyak 7 responden $(53,9 \%)$ merasakan nyeri sedang, dan sebanyak 4 responden $(30,8 \%)$ merasakan nyeri berat sebelum terapi musik, tetapi, sesudah terapi musik sebanyak 8 responden $(61,5 \%)$ merasakan sebelum terapi essential oil mawar, sebanyak 3 responden $(60 \%)$ merasakan nyeri sedang, dan sebanyak 1 responden (20\%) merasakan nyeri berat sebelum terapi essential oil mawar. Tetapi, responden tidak merasakan lagi nyeri berat sesudah terapi essensial oil mawar, sebanyak 2 responden $(40 \%)$ merasakan nyeri ringan, sebanyak 3 responden $(60 \%)$ merasakan nyeri sedang.

Berdasarkan Tabel 3 menunjukkan 10 responden yang memiliki paritas multipara, 4 responden $(40 \%)$ merasakan nyeri ringan sebelum terapi essential oil mawar, sebanyak 4 responden $(40 \%)$ merasakan nyeri sedang, dan sebanyak 2 responden (20\%) merasakan nyeri berat sebelum terapi essential oil mawar. Tetapi, responden tidak merasakan lagi nyeri berat sesudah terapi essensial oil mawar, sebanyak 4 responden $(40 \%)$ merasakan nyeri ringan, sebanyak 6 responden $(60 \%)$ merasakan nyeri sedang.

Berdasarkan Tabel 3 menunjukkan 2 responden yang memiliki paritas grande multipara, responden tidak merasakan nyeri ringan sebelum nyeri ringan, sebanyak 4 responden $(30,8 \%)$ merasakan nyeri sedang, dan hanya 1 responden $(7,7 \%)$ yang nyeri berat. 17 responden yang mendapatkan dukungan keluarga, 5 (29,4\%) responden merasakan nyeri ringan sebelum terapi essential oil mawar, sebanyak 8 responden $(47 \%)$ merasakan nyeri sedang sebelum terapi essential oil mawar, dan sebanyak 4 responden $(23,6 \%)$ merasakan nyeri berat sebelum terapi essential oil mawar. Tetapi, sesudah terapi essensial oil mawar responden tidak lagi merasakan nyeri berat, sebanyak 8 responden (47\%) merasakan nyeri ringan, dan sebanyak 9 responden $(53 \%)$ merasakan nyeri sedang.

Berdasarkan Tabel 3 menunjukkan 17 responden yang mendapatkan dukungan keluarga, $2(11,8 \%)$ responden merasakan nyeri ringan sebelum terapi musik, sebanyak 8 responden (47\%) merasakan nyeri sedang sebelum terapi musik, dan sebanyak 7 responden $(41,2 \%)$ merasakan nyeri berat sebelum terapi musik. Tetapi, sesudah terapi musik responden tidak lagi merasakan nyeri berat, sebanyak 8 responden $(47 \%)$ merasakan nyeri ringan, dan sebanyak 9 responden $(53 \%)$ merasakan nyeri sedang. 


\section{PEMBAHASAN}

Persalinan merupakan suatu kondisi fisiologis yang dialami oleh wanita usia subur pada setiap hasil konsepsi denganproses pengeluaran bayi, plasenta dan selaput ketuban yang keluar dari uterus ibu. Persalinan dianggap normal jika prosesnya terjadi pada usia kehamilan cukup bulan (setelah 37 minggu) tanpa disertai adanya penyulit. ${ }^{9}$ Nyeri adalah sensori subyektif dan emosional yang tidak menyenangkan yang terkait dengan kerusakan jaringan aktual maupun potensial, atau menggambarkan kondisi terjadinya kerusakan. Dengan diberikan terapi musik sangatlah efektif bagi ibu-ibu yang akan melahirkan, sebagai audionalgesik atau penenang yang dapat menimbulkan pengaruh biomedis positif. Seperti untuk mengalihkan perhatian dari rasa sakit atau bisa merubah dan menurunkan tingkat persepsi terhadap rasa sakit sehingga proses persalinan tidak menimbulkan trauma. ${ }^{10}$

Nyeri persalinan kala 1 diakibatkan oleh adanya dilatasi serviks dan segmen bawah uterus dan distensi korpus uteri Tingkat nyeri kala 1 terjadi karena adanya kekuatan kontraksi uterus dan dorongan atau tekanan yang tinggi. Beberapa penelitian menunjukkan bahwa dengan melakukan inhalasi pada aromaterapi mampu menurunkan tingkat nyeri seseorang juga menyebutkan bahwa inhalasi terhadap minyak essensial dapat meningkatkan kesadaran dan menurunkan nyeri. Dampak positif aromaterapi terhadap penurunan tingkat nyeri disebabkan karena aromaterapi diberikan secara langsung (inhalasi). ${ }^{11}$

Mekanisme melalui penciuman jauh lebih cepat dibanding rute yang lain dalam penanggulangan problem emosional seperti stress dan kecemasan, nyeri, karena hidung/penciuman mempunyai kontak langsung dengan bagian-bagian otak yang bertugas merangsang terbentuknya efek yang ditimbulkan oleh aromaterapi. ${ }^{12}$ Hidung sendiri bukanlah organ untuk membau, tetapi hanya memodifikasi suhu dan kelembaban udara yang masuk. Saraf otak (cranial) pertama betanggung jawab terhadap indera pembau dan menyampaikan pada sel-sel reseptor.

Ketika aromaterapi dihirup, molekul yang mudah menguap dari minyak tersebut dibawa oleh udara ke "atap" hidung dimana silia-silia yang lembut muncul dari sel-sel reseptor. Ketika molekul-molekul itu menempel pada rambut- rambut tersebut, suatu pesan elektro kimia akan ditransmisikan melalui bola dan olfactory ke dalam sistem limbic. Hal ini akan merangsang memori dan respons emosional. ${ }^{13}$ Hipotalamus berperan sebagai relax dan regulator, memunculkan pesan-pesan ke bagian otak serta bagian tubuh yang lain. Pesan yang diterima kemudian diubah menjadi tindakan yang berupa pelepasan senyawa elektrokimia yang menyebabkan euporia, relaks atau sedative. Aroma minyak atsiri yang tepat dan menenangkan dapat mengurangi rasa sakit persalinan. ${ }^{14}$ Jenis minyak atsiri yang aman digunakan untuk kehamilan dan persalinan antara lain rose, jasmine, lemon, lavender, dan pine. Minyak atsiri rose atau mawar disebut sebagai queen of oils.

Penggunaan aromaterapi saat proses persalinan dapat memperbaiki per-sepsi ibu terhadap nyeri, membantu perubahan psikologi, suasana hati dan tingkat kecemasan. Beberapa bahan kimia yang terkandung dalam minyak atsiri bunga mawar diantaranya sitral, sitronelol, geraniol, linalol, nerol, eugenol, feniletil, alhohol, farnesol, nonil, dan aldehida. ${ }^{15}$ Pada penelitian ini rata-rata intensitas nyeri sesudah terapi essential oil mawar pada ibu Inpartu Kala I Fase aktif lebih besar dari pada rata-rata intensitas nyeri sesudah terapi musik pada ibu Inpartu Kala I Fase aktif. Hal ini menunjukkan intensitas nyeri sesudah terapi essential oil mawar pada ibu Inpartu Kala I Fase aktif lebih tinggi dibandingkan intensitas nyeri sesudah terapi musik pada ibu Inpartu KalaI Fase aktif. Sehingga, pemberian terapi musik lebih efektif menurunkan intensitas nyeri pada ibu Inpartu Kala I Fase aktif dibandingkan pemberian terapi essential oil mawar.

Terapi musik disini dapat menurunkan skala nyeri. Intensitas nyeri sebelum diberikan terapi musik klasik adalah nyeri sedang dengan skala 4-6 (100\%), setelah diberikan terapi musik klasik kini intensitas nyeri adalah $59,1 \%$ yang mengalami nyeri sedang dan $40,9 \%$ yang mengalami nyeri ringan. ${ }^{16}$ Tingkat nyeri persalinan kala 1 pada saat proses persalinan terjadi karena aktivitas besar di dalam tubuh guna mengeluarkan bayi. Persalinan diartikan sebagai peregangan pelebaran mulut rahim. Kejadian itu terjadi ketika otot-otot rahim berkontraksi untuk mendorong bayi keluar. Otototot rahim menegang selama kontraksi. 
Bersamaan dengan setiap kontraksi, kandung kemih, rektum, tulang belakang, dan tulang pubis menerima tekanan kuat dari rahim. ${ }^{17}$

Banyak para ibu yang mengalami nyeri di bagian punggung mereka saat proses persalinan, yang kemudian menjalar ke bagian depan. Proses kontraksi ini terasa seperti kram atau yang biasanya di alami oleh para wanita saat haid. Hal ini menunjukkan bahwa sebagian ibu bersalin memang mengalami nyeri saat persalinan. ${ }^{18}$ Rasa nyeri dalam persalinan kala 1 menimbulkan efek tersendiri bagi setiap ibu bersalin. Peningkatan sistem saraf simpatik ini timbul sebagai respon terhadap nyeri yang dirasakan oleh ibu,diantaranya dapat mengakibatkan perubahan tekanan darah, denyut nadi, pernafasan tidak teratur, merasa seperti mual dan ingin muntah, keringat berlebihan juga sangatsering terjadi. ${ }^{19}$

Upaya dalam menangani nyeri ibu saat persalinan khususnya pada ibu primipara

\section{KESIMPULAN}

Terapi musik merupakan salah satu dari tekhnik distraksi, manfaat terapi musik dalam proses persalinan disini sangat berfungsi untuk mengatasi kecemasan da mengurangi rasa sakit. Sedangkan bagi para penderita nyeri kronis

\section{UCAPAN TERIMA KASIH}

Peneliti berterima kasih kepada Praktik Mandiri Bidan Hj.SS yang sudah memfasititasi

\section{DAFTAR PUSTAKA}

1. Kemenkes, RI. 2017. Profil Kesehatan Indonesia 2016.Jakarta

2. Kemenkes RI, 2017. Survei Demografi dan Kesegatan 2017.Jakarta

3. Adams J. 2012. Massage an Other CAM In Pregnancy."Internasional Journal of Childbirth Education.

4. Dahny A. 2018. Essential Oil and Massage In Intrapartum Care." The Practising Midwife..

5. Ardiawan, 20016. Macam-Macam Alat Musik Tradisional.Bandung:Sinar Mulia.

6. Koensoemardiyah. 2017.Aromaterapi Untuk Kesehatan, Kebugaran dan merupakan salah satu solusi yang bermanfaat bagi ibu dan janinnya.Adapun metode untuk mengendalikan rasa nyeri selama proses persalinanberlangsung, yaitu dengan menggunakan metode farmakologi dan non farmakologi. Metode farmakologi misalnya dengan pemberian obat-obatan analgesik, sedangkan metode non farmakologi ini juga sangat penting untuk pengontrolan nyeri pada ibubersalin karena metode ini tidak membahayakan bagi ibu maupun janinnya dantidak mempunyai efek alergi maupun efek obat. Diantaranya dengan pemberian tekhnik distraksi, relaksasi, massage dan masih banyak lagi cara lainnya.

Distraksi merupakan suatu tindakan untuk memfokuskan perhatian pasien pada suatu hal atau melakukan pengalihan ke hal-hal diluar nyeri. Distraksi diduga dapat menurunkan persepsi nyeri dengan stimulasi yang langsung di sebarkan ke otak.

akibat suatupenyakit terapi musik terbukti membantu mengatasi rasa sakit. Perlu dilakukan penelitian lebih lanjut dengan jumlah sampel yang lebih besar.

peneliti dari awal pengambilan data sampai penelitian ini selesai dilakukan.

7. Kheirkhah M. 2016. Effect of Aromatherapy with Essential Damask Rose Oil on Anxiety of The Active Phase of Labor Nulliparous Women."Journal of Urmia Nursing \& Midwifery Faculty.

8. Kasjono H. 2018.Teknik Sampling Untuk Penelitian Kesehatan.Yogyakarta:Graha Ilmu

9. Rohani. 2017.Asuhan Kebidanan Pada Masa Persalinan.Jakarta:Salemba Medika

10. Judha. 2018.Teori Pengukur Nyeri \& Nyeri Persalinan. Yogyakarta:Nuha Medika

11. Jaelani. 2017. Manfaat Aromaterapi. Jakarta:Pustaka Populer Obor 
(JPP) Jurnal Kesehatan Poltekkes Palembang

Vol. 15, No. 1, Juni 2020, eISSN 2654-3427

DOI: $10.36086 / j p p . v 15 i 1.456$

12. Nilsson U. 2016The Anxiety an Pain Reducing Effects of Music Interventions a Systematic Review.AORN Journal,87(4), 780807.

13. Liu C. 2016. Effects of Music Therapy on Labuor Pain and Anxiety in Taiwanese FirstTime Mothers."JC Clin Nurs.

14. Watt G., 2018.Aromatherapy in Nursing and Mental Exhaustion Health Care."Journal of Contemporary.

15. Rubkahwati. 2017. Profil Minyak Atsiri Mahkota Bunga Mawar (Rosa Hybrida L.) Surabaya:Kultivar Lokal.

16. Kurnia L. 2010. Pengaruh Terapi Musik Terhadap Nyeri Persalinan Pada Klien Intrapartum Kala I di Rumah Bersalin Widuri
Muragan Sleman Yogyakarta.Universitas Yogyakarta.http://www.jurnal.universitas Yogya.ac.id.Diakses pada tanggal 19 Januari 2019

17. Wiknjosastro GH.2017. Buku Acuan Persalinan Normal.Jakarta:JNP-KR

18. Chapman V. 2017. Asuhan Kebidanan Persalinan \& Kelahiran.Jakarta:EGC

19. Anik. 2010. Nyeri Dalam Persalinan. Jakarta:CV.Trans Info Media

20. Sari N M. 2017.Pengaruh Terapi Musik Klasik Terhadap Intesitas Nyeri Pada Ibu Primigravida Kala I Fase Aktif Persalinan.Universitas

Sumatera.http:www.repository.usu.ac.id di akses pada tanggal 16 Januari 2019 